\title{
Remediation capabilities of pilot-scale wetlands planted with Typha aungstifolia and Acorus calamus to treat landfill leachate
}

\author{
Rohit V. Bhagwat*, Dilip B. Boralkar and Ram D. Chavhan
}

\begin{abstract}
Improper management and unsanitary approaches are implemented in disposal of leachate, which has resulted in groundwater pollution at village Uruli Devachi, Pune, India. Various physico-chemical treatment methods are commercially available for leachate treatment. However, the application of biological methods viz. phytoremediation to the municipal solid waste landfill leachate has been limited. We report the remediation ability of Typha aungstifolia and Acrorus calamus that is capable of reducing hazardous constituents from the landfill leachate. After $96 \mathrm{~h}$ of hydraulic retention time (HRT), it was observed that T. aungstifolia-treated sample showed high reduction potential in reducing biochemical oxygen demand, chemical oxygen demand, hardness, total dissolved solids, $\mathrm{Na}, \mathrm{Mg}, \mathrm{Ca}$ and $\mathrm{Ni}$ whereas A. calamus showed greater reduction capacity for alkalinity, $\mathrm{Cl}, \mathrm{Cu}, \mathrm{Zn}$ and $\mathrm{Cr}$. Furthermore, it was also observed that T. aungstifolia withstood longer HRT than A. calamus. In situ application of T. aungstifolia and A. calamus for remediation of landfill leachate carries a tremendous potential that needs to be further explored.
\end{abstract}

Keywords: Landfill, Leachate, Open dumping, Remediation, Treatment

\section{Introduction}

\section{Nature of the problem}

Municipal solid waste (MSW) and its management have become a major concern throughout the world. Asian countries including China (Asian Development Bank (ADB) 2007), Nepal (Asian Development Bank (ADB) 2013), India, Bangladesh, Sri Lanka, Indonesia, Malaysia and the Philippines are facing severe difficulties due to unplanned and rapid urbanisation (Agamuthu and Tanaka 2014). For many decades, landfilling has been the most preferred waste management options in these countries. Most of the times, these landfills are open and unscientific and are located either in urban fringe or in the rural settings. MSW disposal in a landfill generates active biochemical substances in the form of leachates over a period of many years (Jones et al. 2006 and Erdogan and Zaimoglu 2015). Pollution caused by unscientific designs of the landfills

* Correspondence: rvbhagwat@gmail.com

Department of Environmental Sciences, Savitribai Phule Pune University, Ganeshkhind Road, Pune, Maharashtra 411007, India poses a serious threat to biodiversity, soil, subsurface and surface waters and human well-being.

Factors such as waste composition, decomposition rates, stability and meteorological conditions affect the composition of leachate; therefore, its quality is site specific, and variations are frequent (Jones et al. 2006). The downward movement and outward flow of the leachate transfer the contaminants to the groundwater and peripheral areas of the dump site respectively, thereby also affecting surface water (Papadopoulou et al. 2007). Furthermore, human health risks such as infections, skin irritation, nausea, vomiting and headache, while chronic exposure can led to anaemia, kidney damage and cancer, have been reported by various groups (Klinck and Stuart (1999); Raman and Narayanan (2008)) due to use of leachate-contaminated groundwater.

\section{Phytoremediation}

There are many biological, physical, chemical and physico-chemical techniques to treat the leachate, which 
carries its own merits and demerits (Kamaruddin et al. 2015). Remediation using plants is one of the cost-effective and low maintenance techniques where the dynamics of organic and inorganic interactions are used to decompose and degrade potentially harmful elements in the leachate (Jones et al. 2006). Many species from the plant kingdom are known for their remediation abilities (Table 1); however, it is observed that the application of plant species for treatment of landfill leachate has been limited.

\section{Application of remediation method}

Most of the available literature cites ex situ application of plants to treat the landfill leachate in constructed wetlands. Batool and Baig (2015) report the hyperaccumulation capacity of Typha sp. for $\mathrm{Cu}$ whereas Thlaspi caerulescens, Ipomea alpine, Psychotria douarrei, Thlaspi rotundifolium, Astragalus racemosus and Pteris vitatta show hyper accumulation capacities for $\mathrm{Zn}$ and $\mathrm{Cd}, \mathrm{Cu}$, $\mathrm{Ni}, \mathrm{Pb}, \mathrm{Se}$ and As respectively. (Oh et al. 2014); Baskar et al. (2014) have used Typha latifolia for treating domestic sewage at pilot scale. Bose et al. (2008) in a field study at Delhi applied Tyaha angustata L. to assess the uptake and transport mechanism of heavy metals in waste-amended soils in water logged condition. A phytoremediation study was performed at Pariej reservoir, Gujarat, where aquatic macrophytes viz. Ipomoea aquatica, Eichhornia crassipes, Typha angustata, Echinochloa colonum, Hydrilla verticillata, Nelumbo nucifera and Vallisneria spiralis were analysed for heavy metal accumulation (Sharma and Pandey 2014).

Even though it is a promising technology, their full-scale applications for landfill leachate treatment are yet to be explored mainly due to their low remediation rate, longer treatment time and higher space requirement as compared with the other

Table 1 Plant species known for remediation applications

\begin{tabular}{|c|c|c|}
\hline Name of the species & Type of remediation & Reference \\
\hline $\begin{array}{l}\text { Alternanthera sessilis, } \\
\text { Commelina nudiflora, } \\
\text { Paspalum conjugatum, } \\
\text { Typha angustifolia }\end{array}$ & $\begin{array}{l}\text { Turbidity, TDS, } \\
\text { BOD, nitrate, } \\
\text { orthophosphate } \\
\text { in landfill leachate }\end{array}$ & Laily et al. 2017 \\
\hline $\begin{array}{l}\text { Canna indica, Acorus } \\
\text { calamus and Iris } \\
\text { tectorum Maxim. }\end{array}$ & $\begin{array}{l}\text { Pentachlorophenol } \\
\text { contamination }\end{array}$ & Zhao et al. 2017 \\
\hline $\begin{array}{l}\text { Scirpus validus, } \\
\text { Phragmites australis } \\
\text { and Acorus calamus }\end{array}$ & $\begin{array}{l}\text { Nitrate contamination } \\
\text { in Water }\end{array}$ & Li et al. 2016 \\
\hline Saccharum spontaneum & $\begin{array}{l}\text { Bare fly ash (FA) } \\
\text { dumps }\end{array}$ & Pandey et al. 2015 \\
\hline $\begin{array}{l}\text { Typha latifolia, } \\
\text { Phragmites australis }\end{array}$ & $\begin{array}{l}\text { Removal of heavy } \\
\text { metals in landfill } \\
\text { leachate }\end{array}$ & Grisey et al. 2012 \\
\hline
\end{tabular}

commercially available physico-chemical methods. However, its eco-friendly approach is gaining more attention as well as its efficiency in removing pollutants from waste waters (Oh et al. 2014). Therefore, identification and application of plants with higher remediation potential and faster rates is essential. Biological remediation of contaminated sites has been practiced for many decades, but the application of Typha aungstifolia and Acorus calamus to treat landfill leachate has not been reported in India. Therefore, this pilot-scale study was undertaken to examine the abilities of these plant species treating leachate from unsanitary MSW dumpsite. It also offers an important conservationist perspective by using native and easily available plant species instead of exotic varieties such as Eichhornia spp., causing ecological imbalance.

\section{Materials and methods}

\section{Study area}

The study area involves an unsanitary MSW landfill site at the village Uruli Devachi (UD), located approximately $20 \mathrm{~km}$ to the South East of Pune city, India (Fig. 1) (Lat. $18^{\circ} 27^{\prime} 55.6^{\prime \prime} \mathrm{N}$ and Long. $73^{\circ} 57^{\prime} 10.3^{\prime \prime}$ E; elevation at $600 \mathrm{~m}$ above mean sea level.) The site is an open dump and being used for more than 20 years. The dump site receives untreated mixed MSW from the city of Pune (Fig. 2). It was estimated that the landfill site receives about 1050 tonnes per day of untreated mixed solid waste, whereas precise estimation of daily leachate generation is unavailable (Pune Municipal Corporation 2017). No scientific leachate collection was observed during the site visit undertaken 7 years after reporting of ground water contamination by Kale et al. (2010). The leachate is being collected in an unscientifically designed collection pond on the edge of the dump (Fig. 3). This is suggestive of possible leaching of harmful chemicals into the ground water.

\section{Leachate collection}

The sample was collected in pre-cleaned polyethylene containers of $20 \mathrm{~L}$ capacity. The $\mathrm{pH}$ and electrical conductivity (EC) were recorded onsite at the time of sampling using digital $\mathrm{pH}$ and $\mathrm{EC}$ meters, respectively. For the analysis of biochemical oxygen demand (BOD), a $300-\mathrm{mL}$ capacity BOD bottle was used and dissolved oxygen (DO) was fixed onsite. For heavy metal analyses, the sample was separately collected in pre-washed polyethylene containers of $100 \mathrm{~mL}$ capacity. Spatial data was recorded using a Garmin (eTREX-30X) global positioning system.

\section{Selection of plant species}

T. angustifolia and A. calamus are both native to India. $T$. angustifolia is a marshy plant found on the margins 


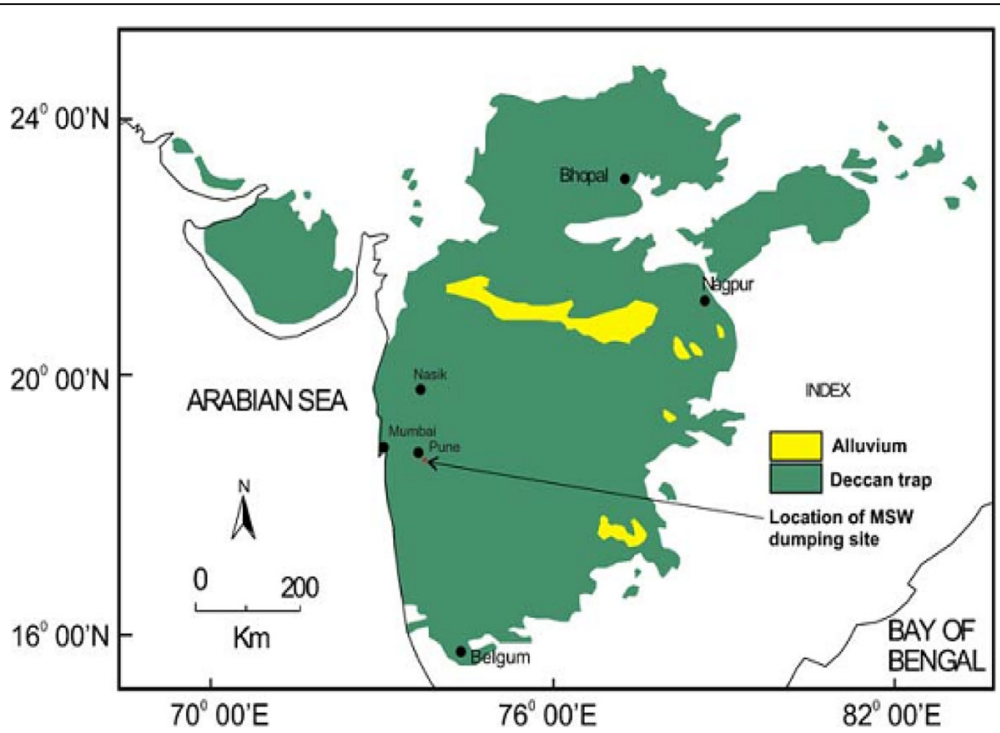

Fig. 1 Location of MSW dumping site at Uruli Devachi (UD), Pune, India (source: Kale et al. 2010)

of shallow lotic systems (Halder et al. 2014), whereas $A$. calamus grows on the margins of standing or slow-flowing water, typically in river backwaters, canal margins and the margins of ponds and lakes (Lansdown 2014). Both of these plants are readily available and easy to grow in marshy areas and have been used for remediation of various pollutants. Therefore, in order to explore their efficiency to treat landfill leachate, these plant species were selected.

\section{Leachate treatment}

In order to deduce the best concentration level for leachate treatment, untreated samples were treated with the $T$. angustifolia and $A$. calamus in three different modes viz. control (raw leachate), 1:1 dilution of leachate to tap water and 1:2 dilution of leachate to tap water along with the control using only tap water. Statistical analysis was performed using Student's $t$ test (Microsoft Excel, 2010) between each of the treatment mode using standard settings in the software to check for the significance of the treatment for $48 \mathrm{~h}$ and $96 \mathrm{~h}$ of HRT respectively.

\section{Wetland mesocosm}

The experimental setup was polyethylene containers with dimensions of $49.5 \mathrm{~cm} \times 32.5 \mathrm{~cm} \times 22 \mathrm{~cm}(L \times B \times H)$. These containers were filled with river sand ( $5 \mathrm{~cm}$ depth) at the bottom and the top layer of garden soil (12 cm depth). The sample was introduced from the top of the container, and water logged conditions were maintained for the period of hydraulic residence time (HRT). The bottom part of

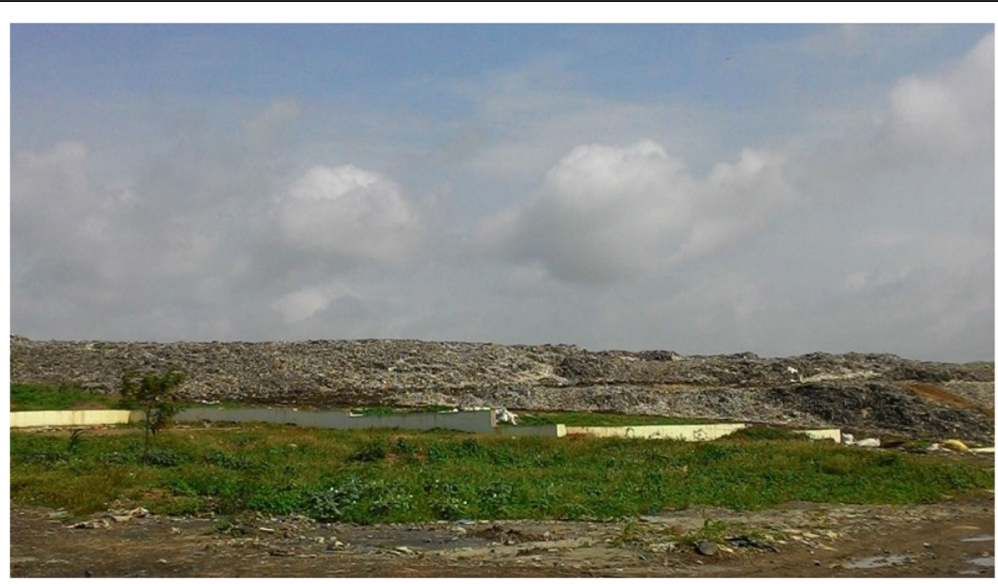

Fig. 2 Open dumping of MSW, UD, Pune, India 


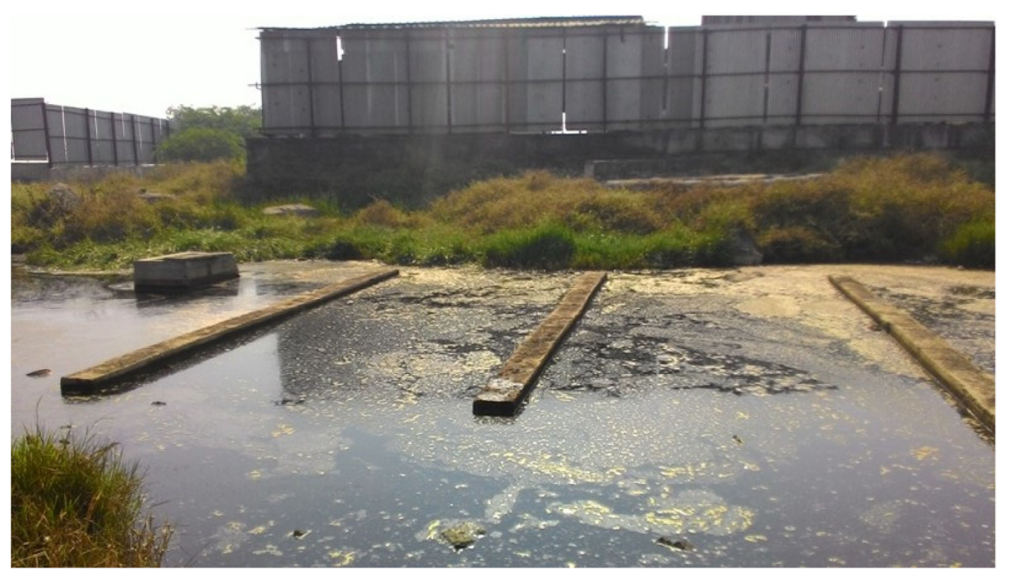

Fig. 3 Unscientific leachate pond at UD landfill, Pune, India

these containers had a control tap (outlet) to extract the samples as per requirement. The experiment was performed in triplicates using $T$. angustifolia and A. calamus in an open air laboratory (Figs. 4 and 5) resembling the landfill site. Every container contained pre-grown and acclimatised plants (six nos.), where T. angustifolia had an average shoot height and root length of $45.5 \pm 6 \mathrm{~cm}$ and $20.1 \pm$ $2.5 \mathrm{~cm}$ respectively. A. calamus had an average shoot height and root length of $21.1 \pm 2.5 \mathrm{~cm}$ and $7.5 \pm 1.2 \mathrm{~cm}$ respectively before they were subjected to the experiment.

Generally, the commercial waste water or leachate treatment units are operated on a shorter residence time with large influx of effluent. Similarly, at the landfill sites, the leachate is generated continuously. Hence, in order to simulate the field conditions, the HRT was maintained for 48 and $96 \mathrm{~h}$, respectively.

\section{Analytical methods}

Immediately after sampling, the collected leachate was brought to the laboratory and refrigerated at temperature below $4{ }^{\circ} \mathrm{C}$. BOD was estimated using the azide modification of Winkler method, while chemical oxygen demand (COD) was determined by open reflux digestion method. Hardness, alkalinity, $\mathrm{Ca}$, and $\mathrm{Cl}^{-}$ were analysed by titrimetry methods (American Public Health Association (APHA) 2012). Na was determined by a flame photometer (Systronic - model no. 128). Total dissolved solids (TDS) and total suspended solids (TSS) were analysed as described previously (American Public Health Association (APHA) (2012)). Mg and trace element viz. $\mathrm{Zn}, \mathrm{Cu}, \mathrm{Ni}, \mathrm{Pb}$ and $\mathrm{Cr}$ concentrations were determined by multispectral inductive coupled plasma-optical emission spectroscopy (ICP-OES) (model: SPECTRO ARCOS- config. FHM22).

\section{Results}

Leachate characterisation

The leachate sample was analysed for 18 physicochemical parameters including the analysis of five heavy metals. The average leachate composition is shown in Table 2 along with the comparison with available literature and standards prescribed by the Government of

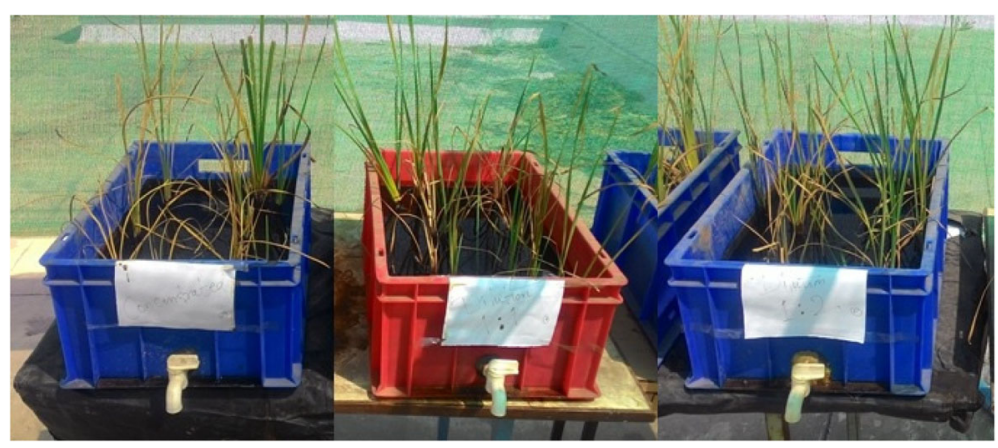

Fig. 4 Experiment setup for T. angustifolia [treated control, 1:1 dilution and 1:2 dilutions (left to right)] 


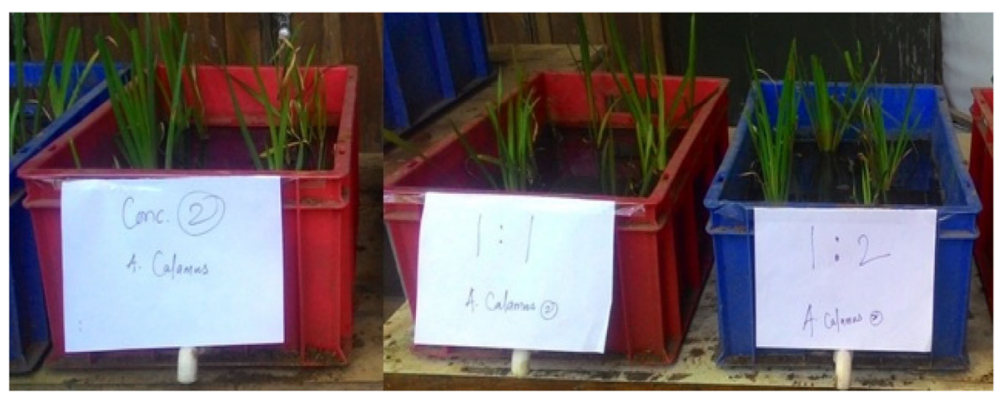

Fig. 5 Experiment setup A. calamus [treated control, 1:1 dilution and 1:2 dilutions (left to right)]

India (GoI) under various rules and guidelines. The leachate composition shows variations since 2006 until now due to dumping of untreated mixed waste at the UD dumping site. Various leachate parameters viz. $\mathrm{pH}$, $\mathrm{Cl}$, TDS, hardness, $\mathrm{Cu}, \mathrm{Pb}$ and $\mathrm{Cr}$ concentrations exceed the drinking water standards IS 10500:2012 (Bureau of Indian Standards (BIS) 2012) and parameters such as $\mathrm{BOD}, \mathrm{TDS}, \mathrm{Ni}, \mathrm{Pb}$ and $\mathrm{Cr}$ against the standards for disposal of treated leachate (Ministry of Environment, Forest and Climate Change (MoEF\& CC) 2016).
Treatment of landfill leachate using $T$. angustifolia and $A$. calamus

Both species showed potential to reduce various leachate constituents after $48 \mathrm{~h}$ and $96 \mathrm{~h}$ of residence time respectively (Tables 3, 4, 5 and 6 and Figs. 6 and 7). Statistical analysis ( $t$ test, $p=0.049-0.01$ ) shows that the experiment results are significantly correlated suggesting effective leachate treatment using two plant species. $T$. aungstifolia showed higher potential for BOD (up to $56 \%$ ), COD (up to $59 \%$ ), hardness (up to $28 \%$ ), TDS (up

Table 2 Leachate composition at the UD landfill site

\begin{tabular}{|c|c|c|c|c|c|c|}
\hline Sr. no & $\begin{array}{l}\text { Sample } \\
\text { constituent }\end{array}$ & $2016^{a}$ & $2008^{* a}$ & $2006^{\# a}$ & $\begin{array}{l}\text { Standards mode } \\
\text { of disposal- } \\
\text { land disposal }\end{array}$ & $\begin{array}{l}\text { Drinking water } \\
\text { specifications- } \\
\text { acceptable limit }\end{array}$ \\
\hline 1 & $\mathrm{pH}$ & 8.9 & 7.8 & 8.33 & $5.5-9.0$ & $6.5-8.5$ \\
\hline 2 & $\mathrm{BOD}$ & 499 & 4.6 & 4122 & 100 & $A B$ \\
\hline 3 & COD & 897 & 36 & 6834 & $A B$ & $A B$ \\
\hline 4 & EC & 3179 & 10,700 & 99,510 & $A B$ & $A B$ \\
\hline 5 & Hardness & 10,000 & 2440 & 2200 & $A B$ & 200 \\
\hline 6 & Alkalinity & 1378 & NA & 2170 & $A B$ & 200 \\
\hline 7 & $\mathrm{Cl}$ & 213 & 4558 & 4485 & 600 & 250 \\
\hline 8 & TDS & 2130 & 6848 & 11,800 & 2100 & 500 \\
\hline 9 & TSS & 8929 & NA & NA & 200 & $A B$ \\
\hline 10 & TS & 11,059 & NA & NA & $A B$ & $A B$ \\
\hline 11 & $\mathrm{Na}$ & 4439 & 3150 & 2550 & $A B$ & $A B$ \\
\hline 12 & $\mathrm{Mg}$ & 2430 & 348 & 110.5 & $A B$ & 30 \\
\hline 13 & $\mathrm{Ca}$ & 4000 & 512 & 340.5 & $A B$ & 75 \\
\hline 14 & $\mathrm{Cu}$ & 2.66 & NA & 0.9 & $A B$ & 0.05 \\
\hline 15 & $\mathrm{Ni}$ & 3.31 & NA & 2.05 & $A B$ & 0.02 \\
\hline 16 & $\mathrm{~Pb}$ & 1.44 & NA & 0.84 & $A B$ & 0.01 \\
\hline 17 & $\mathrm{Zn}$ & 4.66 & NA & 1.63 & $A B$ & 5 \\
\hline 18 & $\mathrm{Cr}$ & 2.65 & NA & 2.87 & $A B$ & 0.05 \\
\hline
\end{tabular}

$N A$ data not available, $A B$ range not provided

a, b, cAll values are in milligrammes per litre, except pH and EC (in $\mu \mathrm{S} / \mathrm{cm}$ ). *Groundwater Surveys and Development Agency (GSDA) (2008); ${ }^{*}$ Kale et al. (2010);

${ }^{b}$ Ministry of Environment, Forest and Climate Change (MoEF\& CC) (2016); ${ }^{c}$ Bureau of Indian Standards (BIS) (2012) 
Table 3 Pollution reduction potential of $T$. angustifolia (after $48 \mathrm{~h}$ of HRT)

\begin{tabular}{|c|c|c|c|c|c|}
\hline \multirow[t]{2}{*}{ Sr. no } & \multirow{2}{*}{$\begin{array}{l}\text { Sample } \\
\text { constituent }\end{array}$} & \multicolumn{4}{|l|}{ Mean value $^{a}$} \\
\hline & & $\begin{array}{l}\text { Raw leachate } \\
\text { (pre-treatment) }\end{array}$ & $\begin{array}{l}\text { Treated } \\
\text { control }\end{array}$ & $\begin{array}{l}\text { 1:1 } \\
\text { dilution }\end{array}$ & $\begin{array}{l}1: 2 \\
\text { dilution }\end{array}$ \\
\hline 1 & $\mathrm{pH}$ & 8.9 & 7.4 & 7.2 & 7.1 \\
\hline 2 & BOD & 499 & 373 & 153 & 111 \\
\hline 3 & $C O D$ & 897 & 638 & 262 & 190 \\
\hline 4 & EC & 3179 & 2654 & 2564 & 2546 \\
\hline 5 & Hardness & 10,000 & 6956 & 5333 & 4304 \\
\hline 6 & Alkalinity & 1378 & 599 & 403 & 363 \\
\hline 7 & $\mathrm{Cl}$ & 213 & 172 & 157 & 134 \\
\hline 8 & TDS & 2130 & 1752 & 1695 & 1588 \\
\hline 9 & TSS & 8929 & 6225 & 3019 & 2179 \\
\hline 10 & TS & 11,059 & 8136 & 4865 & 4012 \\
\hline 11 & $\mathrm{Na}$ & 4439 & 4128 & 3985 & 3266 \\
\hline 12 & $\mathrm{Mg}$ & 2430 & 1690 & 1296 & 1046 \\
\hline 13 & $\mathrm{Ca}$ & 4000 & 2782 & 2133 & 1722 \\
\hline
\end{tabular}

${ }^{\mathrm{a}}$ All values are in milligrammes per litre, except $\mathrm{pH}$ and $\mathrm{EC}$ (in $\mu \mathrm{S} / \mathrm{cm}$ )

to $9 \%$ ), $\mathrm{Na}$ (up to $22 \%$ ), $\mathrm{Mg}$ (up to $28 \%$ ), $\mathrm{Ca}$ (up to $28 \%$ ) and trace elements such as $\mathrm{Ni}$ (up to $18 \%$ ) and $\mathrm{Pb}$ (up to $6 \%$ ) whereas A. calamus showed higher reduction potential for alkalinity (up to $17 \%$ ), chlorides (up to $3 \%$ ) and trace elements viz. $\mathrm{Cu}$ (up to $15 \%$ ), $\mathrm{Zn}$ (up to $8 \%$ ) and Cr (up to 11\%). Additionally, out of the two plants, $T$. angustifolia was found more robust and showed more resilience towards harmful components of the leachate.

Table 4 Pollution reduction potential of A. calamus (after $48 \mathrm{~h}$ of HRT)

\begin{tabular}{|c|c|c|c|c|c|}
\hline \multirow[t]{2}{*}{ Sr. no } & \multirow{2}{*}{$\begin{array}{l}\text { Sample } \\
\text { constituent }\end{array}$} & \multicolumn{4}{|l|}{ Mean value ${ }^{a}$} \\
\hline & & $\begin{array}{l}\text { Raw leachate } \\
\text { (pre-treatment) }\end{array}$ & $\begin{array}{l}\text { Treated } \\
\text { control }\end{array}$ & $\begin{array}{l}\text { 1:1 } \\
\text { dilution }\end{array}$ & $\begin{array}{l}1: 2 \\
\text { dilution }\end{array}$ \\
\hline 1 & $\mathrm{pH}$ & 8.9 & 7.3 & 7.1 & 7.1 \\
\hline 2 & $\mathrm{BOD}$ & 499 & 409 & 360 & 304 \\
\hline 3 & COD & 897 & 736 & 647 & 548 \\
\hline 4 & EC & 3179 & 2614 & 2557 & 2550 \\
\hline 5 & Hardness & 10,000 & 7246 & 6323 & 5365 \\
\hline 6 & Alkalinity & 1378 & 584 & 394 & 356 \\
\hline 7 & $\mathrm{Cl}$ & 213 & 158 & 140 & 128 \\
\hline 8 & TDS & 2130 & 1911 & 1846 & 1765 \\
\hline 9 & TSS & 8929 & 7218 & 4020 & 2390 \\
\hline 10 & TS & 11,059 & 8970 & 5733 & 4098 \\
\hline 11 & $\mathrm{Na}$ & 4439 & 4224 & 4014 & 3890 \\
\hline 12 & $\mathrm{Mg}$ & 2430 & 1761 & 1536 & 1304 \\
\hline 13 & $\mathrm{Ca}$ & 4000 & 2898 & 2529 & 2146 \\
\hline
\end{tabular}

${ }^{\mathrm{a}}$ All values are in milligrammes per litre, except $\mathrm{pH}$ and $\mathrm{EC}$ (in $\mu \mathrm{S} / \mathrm{cm}$ )
Table 5 Pollution reduction potential of T. angustifolia (after $96 \mathrm{~h}$ of HRT)

\begin{tabular}{llllll}
\hline $\begin{array}{l}\text { Sr. } \\
\text { no }\end{array}$ & $\begin{array}{l}\text { Sample } \\
\text { constituent }\end{array}$ & Mean value & & & \\
\cline { 3 - 6 } & & $\begin{array}{l}\text { Raw leachate } \\
\text { (pre-treatment) }\end{array}$ & $\begin{array}{l}\text { Treated } \\
\text { control }\end{array}$ & $1: 1$ dilution & $1: 2$ dilution \\
\hline 1 & pH & 8.9 & 7.3 & 7.1 & 7.1 \\
2 & BOD & 499 & 310 & 101 & 77 \\
3 & COD & 897 & 530 & 173 & 132 \\
4 & EC & 3179 & 2596 & 2550 & 2543 \\
5 & Hardness & 10,000 & 5247 & 4429 & 2886 \\
6 & Alkalinity & 1378 & 466 & 246 & 187 \\
7 & Cl & 213 & 158 & 145 & 128 \\
8 & TDS & 2130 & 1685 & 1635 & 1533 \\
9 & TSS & 8929 & 4666 & 2459 & 1859 \\
10 & TS & 11,059 & 6405 & 4168 & 3562 \\
11 & Na & 4439 & 3556 & 1860 & 1628 \\
12 & Mg & 2430 & 1275 & 1076 & 701 \\
13 & Ca & 4000 & 2099 & 1771 & 1154 \\
\hline aAll values are in milligrammes per litre, except pH and EC (in $\mu$ S $/ \mathrm{cm})$
\end{tabular}

${ }^{\mathrm{a}}$ All values are in milligrammes per litre, except $\mathrm{pH}$ and $\mathrm{EC}$ (in $\mu \mathrm{S} / \mathrm{cm}$ )

\section{Discussion}

The landfill site at village UD is being operated for more than 20 years. The leachate generated at the dump site is disposed without any scientific intervention, where it percolates to the local aquifer and contaminates the groundwater. The characterisation of leachate undertaken herein demonstrates its potential of impacting the soil quality and groundwater in the surrounding areas.

Table 6 Pollution reduction potential of A. calamus (after $96 \mathrm{~h}$ of HRT)

\begin{tabular}{|c|c|c|c|c|c|}
\hline \multirow[t]{2}{*}{ Sr. no } & \multirow{2}{*}{$\begin{array}{l}\text { Sample } \\
\text { constituent }\end{array}$} & \multicolumn{4}{|l|}{ Mean value } \\
\hline & & $\begin{array}{l}\text { Raw leachate } \\
\text { (pre-treatment) }\end{array}$ & $\begin{array}{l}\text { Treated } \\
\text { control }\end{array}$ & $\begin{array}{l}1: 1 \\
\text { dilution }\end{array}$ & $\begin{array}{l}1: 2 \\
\text { dilution }\end{array}$ \\
\hline$\overline{1}$ & $\mathrm{pH}$ & 8.9 & 7.2 & 7.1 & 7.1 \\
\hline 2 & BOD & 499 & 367 & 196 & 176 \\
\hline 3 & COD & 897 & 661 & 353 & 316 \\
\hline 4 & $\mathrm{EC}$ & 3179 & 2564 & 2543 & 2536 \\
\hline 5 & Hardness & 10,000 & 6219 & 5788 & 3985 \\
\hline 6 & Alkalinity & 1378 & 430 & 204 & 184 \\
\hline 7 & $\mathrm{Cl}$ & 213 & 157 & 141 & 126 \\
\hline 8 & TDS & 2130 & 1740 & 1704 & 1680 \\
\hline 9 & TSS & 8929 & 5812 & 3970 & 3160 \\
\hline 10 & TS & 11,059 & 7530 & 5673 & 4859 \\
\hline 11 & $\mathrm{Na}$ & 4439 & 3789 & 2370 & 1762 \\
\hline 12 & $\mathrm{Mg}$ & 2430 & 1511 & 1407 & 968 \\
\hline 13 & $\mathrm{Ca}$ & 4000 & 2488 & 2315 & 1594 \\
\hline
\end{tabular}

${ }^{\mathrm{a}}$ All values are in milligrammes per litre, except $\mathrm{pH}$ and $\mathrm{EC}$ (in $\mu \mathrm{S} / \mathrm{cm}$ ) 


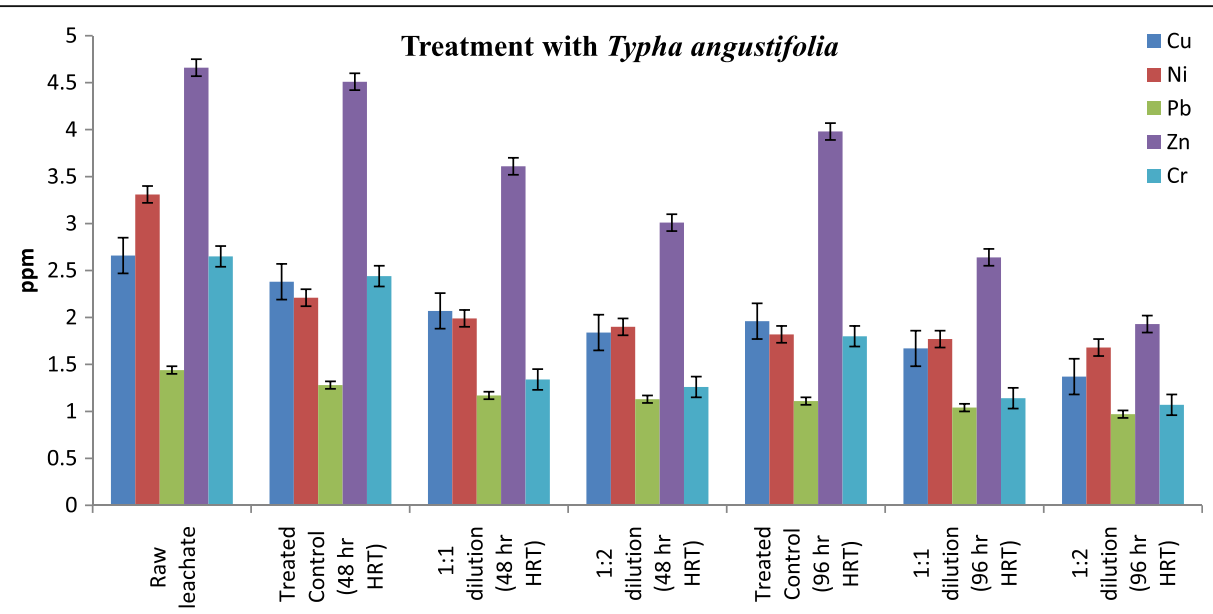

Fig. 6 Reduction of trace elements after treatment using T. angustifolia (48 h of HRT; error bars represent standard deviation; Student's $t$ test, $p=$ 0.049-0.01 and $96 \mathrm{~h}$ of HRT; error bars represent standard deviation; Student's $t$ test, $p=0.049-0.01$ )

Therefore, it is necessary to scientifically design the landfill site to dispose of MSW and collection of hazardous leachate, which can be treated further and disposed without causing any harm to the environment. Remediation can be limited in case of plant application due to retention of chemicals on the soil particles. This may vary depending upon charge on soil and its respective adsorption dynamics. Further, the microbial consortium in leachate and soil may hinder or accentuate remediation in the wetland mesocosm.

\section{Remediation potential of $T$. angustifolia and $A$. calamus}

Pilot-scale application of T. angustifolia and A. calamus to treat landfill leachate demonstrates that both species were capable of reducing various pollutants from the leachate. The method provides a natural, cost-effective, low maintenance method to treat leachate. With appropriate pre-treatment of the leachate, both species would provide an effective alternative to the costly leachate treatment processes such as reverse osmosis. However, the process is slow and requires higher space for treatment as compared to commercial methods. During the experimentation, it was also observed that $T$. angustifolia is more robust and capable of withstanding heavy loads of contaminants even after $96 \mathrm{~h}$ of residence time as compared to A. calamus.

\section{Conclusion}

Direct disposal of untreated MSW landfill leachate on the open sites poses a serious threat to the community health and environment due to its harmful components. An appropriate landfill design would reduce the threat

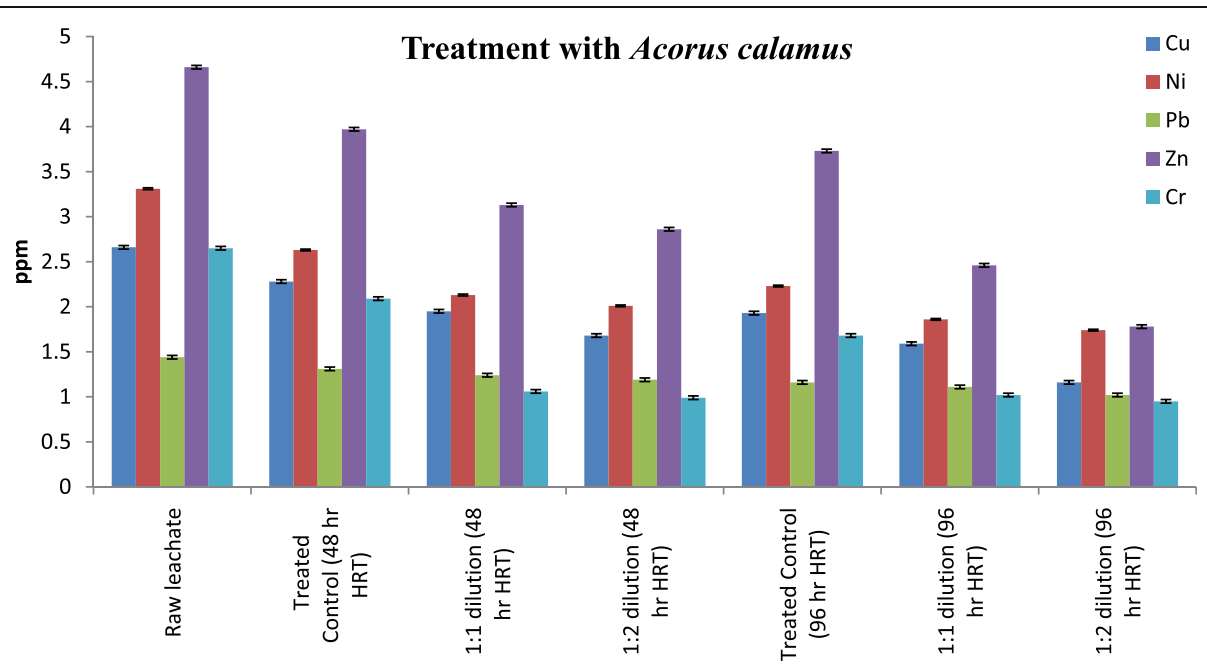

Fig. 7 Reduction of trace elements after treatment using A. calamus (48 h of HRT; error bars represent standard deviation; Student's $t$ test, $p=$ 0.049-0.01 and $96 \mathrm{~h}$ of HRT; error bars represent standard deviation; Student's $t$ test $p=0.049-0.01$ ) 
of leachate pollution by collecting it scientifically, which is also essential for leachate remediation. Herein, we show that plants have potential and offer an eco-friendly alternative for leachate treatment. Application of $T$. angustifolia and A. calamus has shown positive results in reducing hardness, alkalinity and $\mathrm{Cl}$ along with trace elements such as $\mathrm{Cu}, \mathrm{Pb}, \mathrm{Ni}$ and $\mathrm{Cr}$ in the tested samples. T. angustifolia was more robust of the two species and could sustain longer HRT. These results highlight the remediation potential of these two species, and hence, in situ applicability of these plant species needs to be further explored.

\section{Acknowledgements}

We thank Professor Nitin Karmalkar, Vice Chancellor, Savitribai Phule Pune University (SPPU), and Professor Suresh Gosavi, Head, Department of Environmental Science, SPPU, for providing the access to all necessary facilities. The authors express their gratitude towards Professor Venkat Gunale for the continuous encouragement and support.

\section{Funding}

No funding available

\section{Availability of data and materials}

The datasets during the current study are available from the corresponding author on reasonable request.

\section{Authors' contributions}

RVB and DBB formulated the idea, drafted the manuscript and wrote the final text. RVB and RDC performed the experiments, and RVB analysed the results. All authors read and approved the final manuscript.

\section{Ethics approval and consent to participate}

Not applicable

\section{Consent for publication}

Not applicable

\section{Competing interests}

The authors declare that they have no competing interests.

\section{Publisher's Note}

Springer Nature remains neutral with regard to jurisdictional claims in published maps and institutional affiliations.

Received: 21 September 2018 Accepted: 1 November 2018 Published online: 16 November 2018

\section{References}

Agamuthu P, Tanaka M, editors. Municipal solid waste management in Asia and the Pacific Islands. Challenges and strategic solutions. Singapore: SpringerVerlag; 2014. ISBN 978-981-4451-73-4 (eBook)

American Public Health Association (APHA). Standard methods for the examination water and wastewater. 22nd ed. Washington DC: APHA. AWWA WPCF; 2012.

Asian Development Bank (ADB). (2007). People's Republic of China: urban wastewater and solid waste management for small cities and towns. Technical assistance report.

Asian Development Bank (ADB). (2013). Solid waste management in Nepal: current status and policy recommendations.

Baskar G, Deeptha VT, Annadurai R. Comparison of treatment performance between constructed Wetlands with different plants. In J Res Eng Technol. 2014;03:210-4.

Batool A, Baig MA. Growth behaviour comparison of three species exposed to municipal solid waste leachate in microcosm constructed wetland. London: International Conference on Advances in Agricultural, Biological \&
Environmental Sciences (AABES-2015) July 22-23, 2015; 2015. https://doi.org/ 10.15242/ICBE.C0715094.

Bose S, Vedamati J, Rai V, Ramanathan AL. Metal uptake and transport by Tyaha anqustata L. grown on metal contaminated waste amended soil: an implication of phytoremediation. Geoderma. 2008;145:136-42. https://doi. org/10.1016/j.geoderma.2008.03.009.

Bureau of Indian Standards (BIS). Indian standard, drinking water - specification. $2^{\text {nd }}$ revision. Amendment; 2012. p. 2015.

Erdogan R, Zaimoglu Z. The characteristics of phytoremediation of soil and leachate polluted by landfills: INTECH; 2015. https://doi.org/10.5772/61105

Grisey E, Laffray X, Contoz O, Cavalli E, Mudry J, Aleya L. The bioaccumulation performance of reeds and cattails in a constructed treatment wetland for removal of heavy metals in landfill leachate treatment (Etueffont, France). Water Air Soil Pollut. 2012;223:1723-41. https://doi.org/10.1007/s11270-0110978-3.

Groundwater Surveys and Development Agency (GSDA). (2008). A report on ground water quality in Pune Region.

Halder S, Venu P, Rao YV. The distinct Typha angustifolia (Typhaceae) ignored in Indian floras. Rheedea. 2014;24(1):16-20.

Jones DL, Williamson KL, Owen AG. Phytoremediation of landfill leachate. Waste Manag. 2006;26:825-37. https://doi.org/10.1016/j.wasman.2005.06.014.

Kale SS, Kadam AK, Kumar S, Pawar NJ. Evaluating pollution potential of leachate from landfill site, from the Pune metropolitan city and its impact on shallow basaltic aquifers. Environ Monit Assess. 2010;162:327-46. https://doi.org/10. 1007/s10661-009-0799-7.

Kamaruddin MA, Yusoff MS, Aziz HA, Hung YT. Sustainable treatment of landfill leachate. Appl Water Sci. 2015;5:113-26. https://doi.org/10.1007/s13201-0140177-7.

Klinck BA, Stuart ME. Human health risk in relation to landfill leachate quality. British Geological Survey Technical Report WC/99/17. Keyworth: British geological survey; 1999

Laily S, Yanuwiadi B, Retnaningdyah C. The role of local hydromacrophytes in leachate phytoremediation performed using constructed wetland system. J Exp Life Sci. 2017;7(1)

Lansdown RV. Acorus calamus. The IUCN Red List of Threatened Species 2014: e. T168639A43116307; 2014. https://doi.org/10.2305/IUCN.UK.2014-1.RLTS. T168639A43116307.en.

Li K, Liu L, Yang H, Zhang C, Xie H, Li C. Phytoremediation potential of three species of macrophytes for nitrate in contaminated water. Am J Plant Sci. 2016;7:1259-67. https://doi.org/10.4236/ajps.2016.78121.

Ministry of Environment, Forest and Climate Change (MoEF\& CC). (2016). Solid waste management (SWM) rules, 2016.

Oh K, Cao T, Li T, Cheng H. Study on application of phytoremediation technology in management and remediation of contaminated soils. J Clean Energy Technol. 2014;2(3).

Pandey VC, Bajpai O, Pandey DN, Singh N. Saccharum spontaneum: an underutilized tall grass for revegetation and restoration programs. Genet Resour Crop Evol. 2015;62:443-50.

Papadopoulou MP, Karatzas GP, Bougioukou GG. Numerical modelling of the environmental impact of landfill leachate leakage on groundwater quality - a field application. Environ Model Assess. 2007;12:43-54. https://doi.org/10. 1007/s10666-006-9050-x.

Pune Municipal Corporation. (2017). Presentation before Honourable National Green Tribunal on Solid Waste Management in Pune City - present status and future plan.

Raman N, Narayanan DS. Impact of solid waste effect on groundwater and soil quality nearer to Pallavaram solid waste landfill site in Chennai. Rasayan J Chem. 2008; (4):828-36.

Sharma P, Pandey S. Status of phytoremediation in world scenario. Int J Environ Bioremediation Biodegradation. 2014;2(4):178-91. https://doi.org/10.12691/ ijebb-2-4-5.

Zhao L, Guo W, Li Q, Li H, Zhao W, Cao X. Capabilities of seven species of aquatic macrophytes for phytoremediation of pentachlorophenol contaminated sediment. IOP Conf. Series: Earth Environ Sci. 2017. https://doi.org/10.1088/ $1755-1315 / 51 / 1 / 012030$ 